\title{
Początki napawania utwardzającego
}

\section{Early years of hard-facing}

\section{Streszczenie}

Zaprezentowano pierwsze próby napawania, prowadzone w czasach opanowywania technologii spawalniczych, pierwsze technologie napawania, które zostały zastosowane w praktyce. Przedstawiono pierwsze aplikacje napawania oraz ówczesne zalecenia, dotyczące przygotowania procesu.

Zasygnalizowano ewolucję poglądów na temat możliwych do uzyskania właściwości warstw oraz sposobów wytwarzania materiałów dodatkowych w postaci prętów, drutów i proszków. Przedstawiono także początki bardziej współczesnych technologii napawania: łukiem krytym, plazmowego i in.

\section{Wstęp}

Dziewięćdziesiąt lat temu w USA powstała firma braci Stoody, którą powszechnie uważa się za światowego prekursora utwardzającego napawania regeneracyjnego i uszlachetniającego (ang. hard-facing). Historia napawania jest w rzeczywistości nieco dłuższa i liczy sobie 130 lat, czyli tyle samo, ile klasyczne spawanie.

Napawanie traktowano początkowo jako odmianę spawania - stosowano te same technologie i materiały dodatkowe [1]. Zamiast jednak nadtapiać krawędzie elementów i wypełniać szczelinę między nimi stopionym materiałem dodatkowym, nanoszono go na nadtopioną powierzchnię materiału rodzimego. Wzmianki o wczesnym używaniu napawania do celów regeneracyjnych, np. do odtwarzania geometrii przedmiotów, których krawędzie uległy wyszczerbieniu, nie zawierają szczegółowych informacji na temat stosowanych materiałów i ewentualnych odmienności technologii.

\section{Prekursorzy napawania}

Prekursor spawania łukowego Nikołaj N. Benardos (rys. 1) w swych pierwszych patentach, dotyczących

Dr inż. Tomasz Szulc - Politechnika Wrocławska.
„Metody obróbki metalu za pomocą bezpośrednio użytego prądu elektrycznego", wydanych w Rosji (1885) i innych krajach, wspomina o użyciu materiału dodatkowego o tym samym składzie chemicznym co materiał rodzimy do naprawy odlewów i odtwarzania geometrii zużytych części maszyn (rys. 2) [2, 3]. Podobno napawanie Benardos demonstrował podczas swych wyjazdów do Europy Zachodniej, np. w paryskim laboratorium Electricien Kabatha, już w 1881 r. Z perspektywy czasu należy przyjąć, że utwardzone wskutek silnego nawęglenia stopiwo, powstające w metodzie Benardosa, lepiej nadawało się do napawania niż spawania.
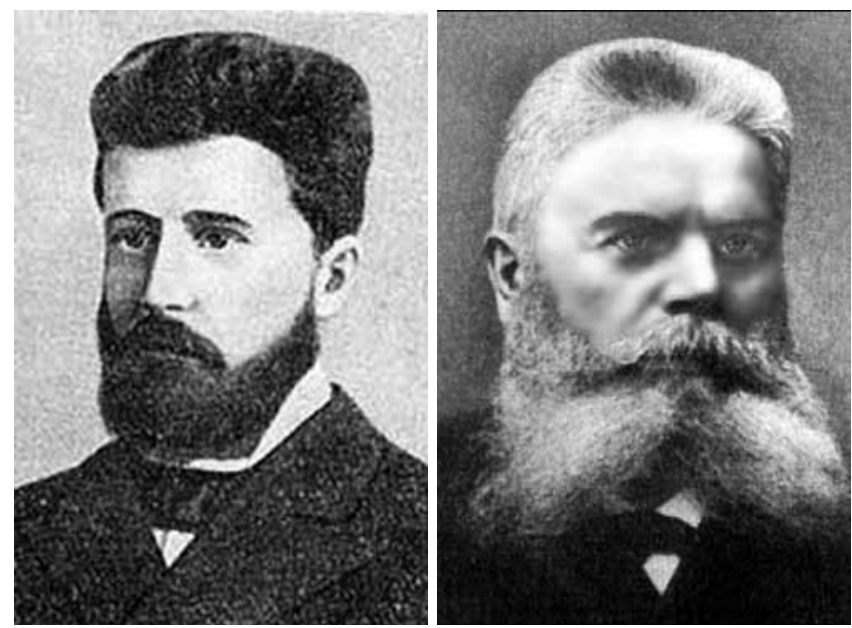

Rys. 1. Nikołaj Benardos [12] Fig. 1. Nikolai Benardos [12] 


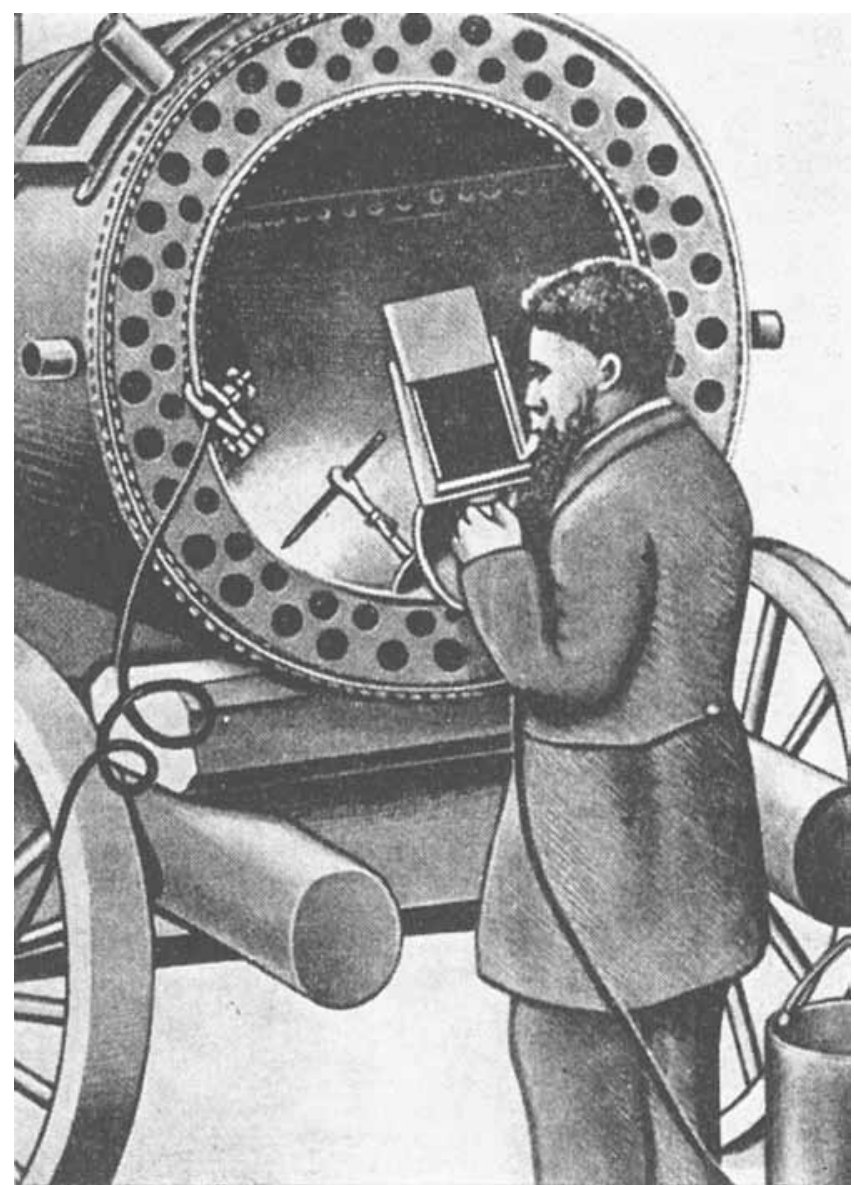

Rys. 2. N. Benardos podczas naprawy pękniętego kotła [3] Fig. 2. N. Benardos during the repair of broken boiler [3]

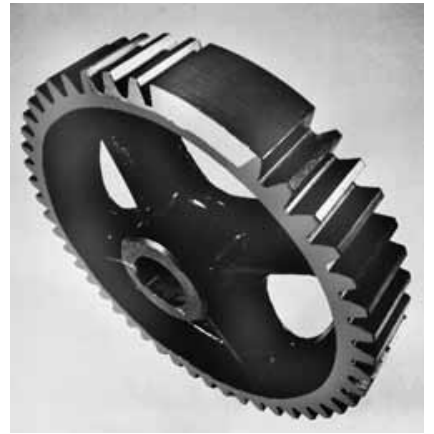

Rys. 3. Koło zębate po naprawczym napawaniu wyłamanych zębów [5]

Fig. 3. The gear after repair cladding of broken tooth [5]

Inny rosyjski spawalnik - Nikołaj Sławianow, pracujący jako inżynier w fabryce broni w Permie (obecnie fabryka Motowilichinskije Zawody) stosował napawanie łukowe do naprawy wadliwych odlewów. W 1890 r. opatentował udoskonaloną metodę Benardosa, w której zamiast grafitowej elektrody stosował jako przewodnik pręt wykonany z metalowego materiału dodatkowego, który nazwał elektrodę, wzorując się na Faradayu. $W$ ciągu trzech lat $w$ fabryce wykonano ponad 1600 takich napraw odlewów; podobno w większości przypadków wykonywał je osobiście Sławianow. Zalecał przy tym wstępne podgrzewanie odlewów [4]. Później skonstruował prototyp głowicy $z$ automatyczną regulacją długości łuku, a w 1896 r. - automat do napawania powierzchni roboczych kół zębatych (rys. 3). We wszystkich opisanych przypadkach stosowano napoiny o składzie chemicznym zbliżonym do materiału rodzimego. Napawanie remontowe kół zębatych pozostało na wiele lat jedną z najchętniej stosowanych aplikacji tej technologii [5].

\section{Rozwój metod napawania}

Napawanie praktykowano także w celu określenia parametrów spawania, próbowano na tej podstawie szacować szerokość lica i głębokość wtopienia możliwe do uzyskania podczas spawania. Metodę tę stosował m.in. Oscar Kjellberg, doskonaląc spawanie łukowe, co doprowadziło do opatentowania przez niego w 1908 r. elektrod otulonych [6].

Pierwszy wniosek patentowy dotyczący możliwości napawania utwardzającego złożył w 1896 r. J. Spencer z Phoenix Iron Works Glasgow, ale prawdopodobnie nie zrealizował w praktyce swego pomysłu [7]. Dlatego za pierwsze praktyczne zastosowanie napawania utwardzającego uznawana jest działalność Amerykanów, braci Winstona i Shelleya Stoody (rys. 4), którzy w 1921 r. założyli w Whittier w Kalifornii zakład Stoody Welding Co. i zajęli się naprawą urządzeń rolniczych oraz traktorów. W tym samym roku w okolicy odkryto złoża ropy naftowej i bracia przerzucili się na naprawy sprzętu wiertniczego. Szybko zauważyli, że najszybciej zużywające się części to tzw. koronki wierteł. Nie zachowały się informacje, jaką drogą błyskawicznie doszli do koncepcji zastosowania napawania utwardzającego do regeneracji, a potem produkcji wierteł (rys. 5). Opracowali materiał dodatkowy w postaci stalowych rurek wypełnionych proszkiem $\mathrm{Cr}_{3} \mathrm{C}_{2}$ i zwanych Stoody Rod (pręt Stoody'ego). Topili go najpierw w płomieniu

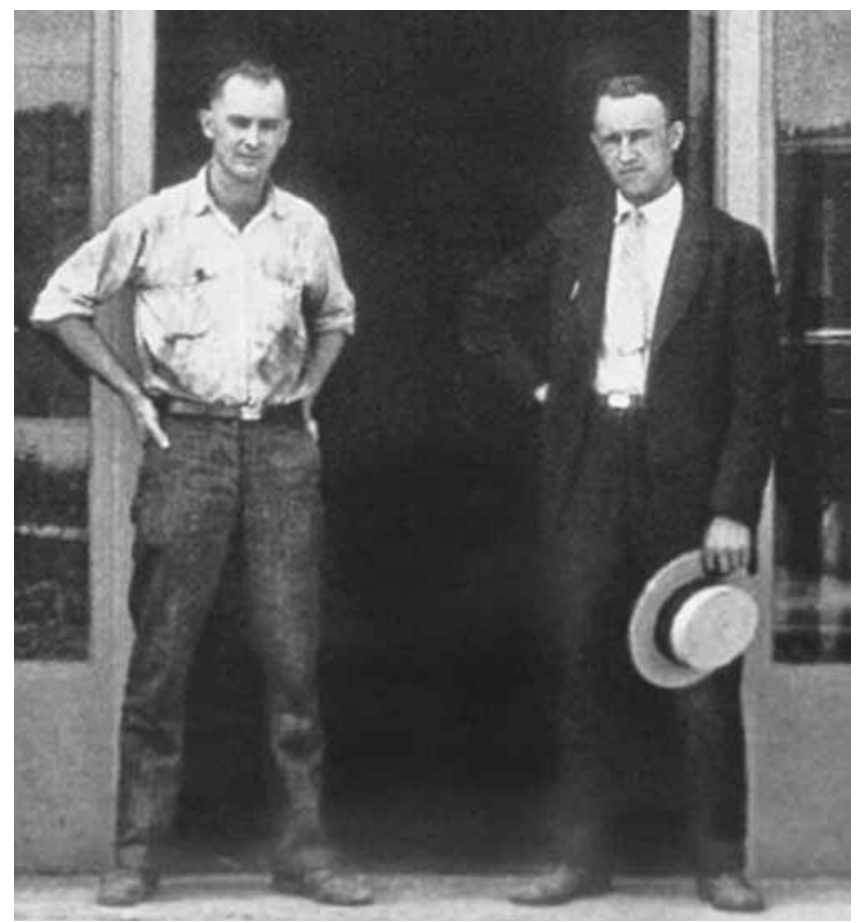

Rys. 4. Bracia Winston i Shelley Stoody [8]

Fig. 4. Winston and Shelley Stoody brothers [8] 


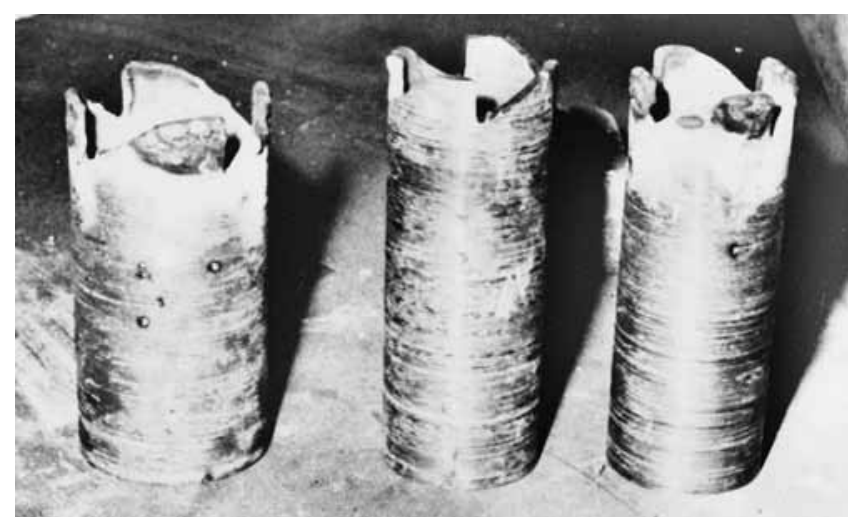

Rys. 5. Napawane utwardzająco koronki wierteł górniczych [5] Fig. 5. Hard faced mining core cutters [5]

acetylenowo-tlenowym, a później za pomocą ciepła łuku elektrycznego [8]. Co ciekawe, pierwsze elektrody z rdzeniem proszkowym opatentował F. Leitner, kierownik stalowni braci Böhler, dopiero w $1925 \mathrm{r}$.

Tymczasem inna technologia napawania utwardzającego zastała jeszcze wcześniej, bo w 1868 r. Wtedy to w kopalni zstała zapoczątkowana miasteczku Deloro (prowincja Ontario) należącej do M.J. O'Briena odkryto wysokogatunkowe pokłady kobaltu. W 1907 r. w Kokomo (Indiana, USA) Elwood Haynes (rys. 6) opatentował twarde stopy na bazie kobaltu, które nazwał stellitami (gra słów: stellite wymawia się tak samo jak stellar light - gwiezdny blask). Sprzedaż stellitów, rosnąca skokowo w czasie I wojny światowej, uczyniła go w 1916 r. milionerem. Odlewane pałeczki stellitowe zaczęto nieco później stosować do płomieniowego napawania utwardzającego, ale popularność metoda zyskała dopiero wówczas, gdy O'Brien i Haynes połączyli w 1917 r. siły, zakładając Deloro Smelting and Refining Ltd (obecnie Deloro Stellite) i otwierając rok później pierwszą filię w Europie - w brytyjskim Birmingham [9]. Pierwsze napawanie zaworów silnika spalinowego prętami stellitowymi przeprowadził w 1922 r. Haynes w swojej fabryce samochodów osobowych w Kokomo [7]. W Europie pierwsze napawanie elementów zaworów miało miejsce w niemieckiej fabryce KSB w 1921 r. (zgodnie z patentem wydanym firmie w Belgii i dotyczącym napawania stali austenitycznej na wyroby ze stali węglowej). Ta sama firma jako pierwsza na Starym Kontynencie zaczęła napawać elementy zaworów stellitami w 1928 r. [10].

Bracia Stoody opracowali tymczasem pręty lane Stoodite (podobieństwo nazw Stoodite i Stellite nie jest przypadkowe), a później opracowali w swym laboratorium pierwszy materiał do napawania utwardzającego zawierający węglik wolframu. Ich niewielka firma rekordowo długo zachowała samodzielność, dopiero w 1988 r. została wykupiona przez Thermadyne Industries, ale zachowała swą nazwę i jako Stoody Division funkcjonuje w Bowling Creek w Kentucky (USA).

W latach dwudziestych XX w. i jeszcze wiele lat później wszelkie zastosowania napawania miały charakter eksperymentalny i nie były poparte rozważaniami
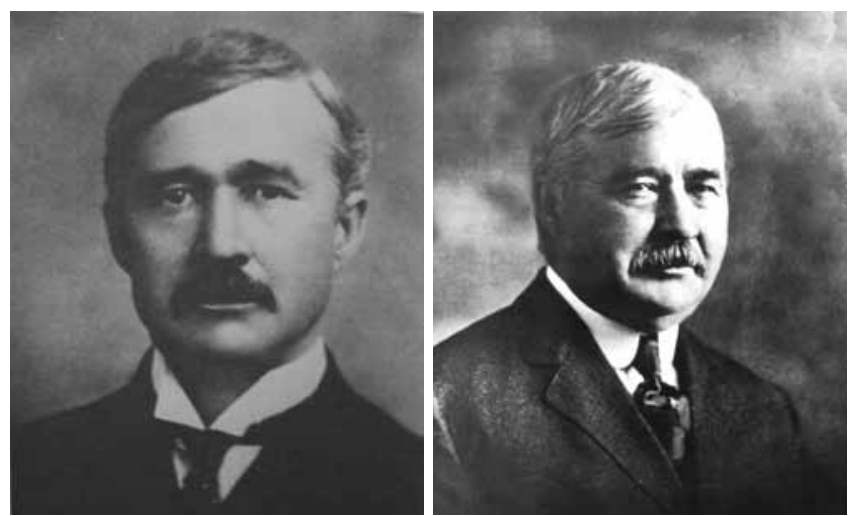

Rys. 6. Elwood Haynes [9]

Fig. 6. Elwood Haynes [9]

o charakterze metalurgicznym. Brak świadomości nierównowagowego przebiegu procesu prowadził do trudności prognozowania naprężeń i odkształceń w materiale. Także ostateczny skład warstwy napawanej był zwykle określany post factum - empirycznie. Takim właśnie sposobem wypracowano zalecenia, dotyczące prowadzenia procesu. Wskazywano na ryzyko pęknięć warstwy napawanej, rosnące wraz z jej grubością, czemu przeciwdziałać miało zastępowanie jednej warstwy dużej grubości kilkoma cieńszymi. W ten sam sposób ograniczano współczynnik wymieszania, czyli zawartość składników podłoża w warstwie. Wstępne podgrzewanie podłoża, zalecane w przypadku napraw odlewów, nie było powszechnie stosowane w napawaniu elementów kutych i walcowanych.

W Europie tymczasem rozwijały się technologie napawania łukowego, które stosunkowo długo traktowano jako odmianę spawania. I tak w 1929 r. D. Dulczewski uzyskał w b. ZSRR patent na spawanie łukiem krytym, które okazało się bardzo wydajną metodą łukowego stapiania materiału dodatkowego, nadająca się do napawania. Licencję na analogiczną metodę zyskała 7 lat później w USA firma Linde, a za amerykańskich prekursorów napawania pod topnikiem uznaje się braci Stoody.

Eksperymentowano także $z$ napawaniem za pomocą leżącej elektrody grafitowej w postaci długiej płytki. Na materiał rodzimy sypano warstwę prażonego boraksu, potem warstwę proszku metalicznego pełniącego funkcję materiału dodatkowego o grubości $3 \div 5 \mathrm{~mm}$ i szerokości $40 \div 60 \mathrm{~mm}$, na niej układano elektrodę nieco dłuższą niż warstwa proszków. Podłączano ją do dodatniego bieguna źródła zasilania i zajarzano łuk. Odmianą tej metody było napawanie leżącą płytkową elektrodą metalową. W tym przypadku płytka stalowa była układana na warstwie topnika pokrywającej materiał rodzimy. $\mathrm{W}$ razie potrzeby na płytkę sypano warstwę proszku stopowego, potem kolejną warstwę granulowanego topnika i całość dociskano płytą miedzianą. Uzyskiwane napoiny miały grubość do $3 \mathrm{~mm}$ [1]. Później rozpoczęto eksperymenty z napawaniem leżącą elektrodą otuloną. Zapoczątkowało je opatentowanie w 1917 r. w USA metody Firecracker, znanej później jako spawanie elektrodą leżącą. 


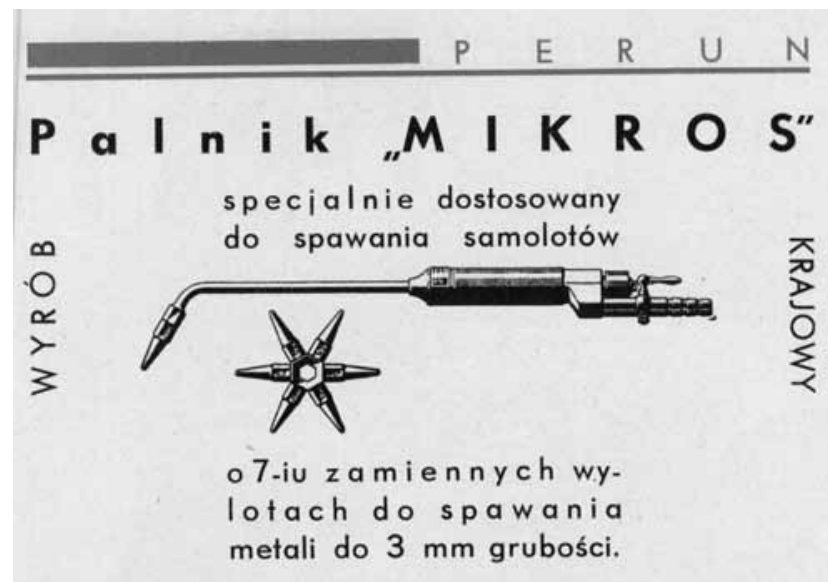

\section{P A L N I K D R O G O W Y na wysokie ciśnienie acetylenu dostosowany do robót zwiqzanych z konserwacja nawierzchni kolejowej, jak napawanie na torze szyn i krzy- żownic zużyłych i t. p. \\ Bliższe szczególy, wraz $x$ pokazem dzialania na osobne żadanie.}

Rys. 7. Reklama polskiego palnika do napawania z 1935 r. [13] Fig. 7. Advertisement of Polish hard-facing burner from 1935 [13]

Do napawania produkowano specjalne elektrody o prostokątnym przekroju. Niektóre źródła np. [7] podają, że za pomocą takiej elektrody w 1939 r. inżynierowie Michajłow $\mathrm{i}$ Łarionow zrealizowali po raz pierwszy w praktyce proces napawania zautomatyzowanego, co jednak budzi wątpliwości dwojakiego rodzaju: po pierwsze znacznie wcześniej zostało opatentowane urządzenie Sławianowa, a od połowy lat 30. ub. w. praktykowano napawanie pod topnikiem, będące $z$ definicji procesem zautomatyzowanym.

$\mathrm{Na}$ dużą skalę praktykowano napawanie elektrodami otulonymi Kjellberga i rdzeniowymi Leitnera, a także elektrodami, których otulinę stanowił owinięty wokół rdzenia sznur azbestowy nasycony związkami chemicznymi. Dla zwiększenia wydajności napawania proponowano stosowanie pakietów lub wiązek elektrod [11]. Co ciekawe, Benardos jeszcze w 1893 r. proponował stosowanie wiązki elektrod grafitowych w celu zwiększenia powierzchni jeziorka spawalniczego [12].

W II Rzeczpospolitej elektrody do napawania produkowała Huta Baildon, a palniki do napawania płomieniowego - zakłady Perun. Podobnie jak w innych krajach europejskich, jednym z głównych użytkowników elementów napawanych były koleje państwowe. W 1935 r. szacowano, że z użyciem krajowych urządzeń poddano regeneracji co najmniej trzy tysiące rozjazdów, zwrotnic i krzyżownic torowych [13]. Typowy zestaw oferowany w tym celu przez Peruna składał się z tzw. acetylenowego palnika drogowego wysokiego ciśnienia (rys. 7) i drutu do napawania Tor (rys. 8). Huta

\section{$P \quad E \quad R \quad U \quad N$}

\section{JUŻ 3000 KRZYŻOWNIC}

naprawiono w Polsce

zapomoca napawania acefylenowo-tlenowego

OTRZYMUJAC ŚWIETNE WYNIKI

dzięki stosowaniu

drutuzestali specialnei

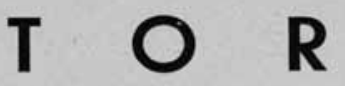

wyrobu krajowego

dostarczanego przez nasza firme

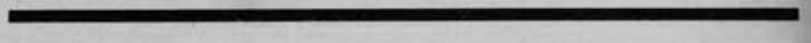

CZYTAJCIE szereg prac Inżynierów Kolejowych

- napawaniu szyn i krzyżownic w Czasopiśmie

"SPAWANIE I CIECIE METALI“" r. 1934 i 1935.

Rys. 8. Reklama polskiego materiału dodatkowego do napawania z 1935 r. [13]

Fig. 8. Advertisement of Polish filler for hard-facing 1935 [13]

Baildon produkowała całą gamę elektrod, nadających się do spawania i napawania, w tym elektrody ze stali wysokomanganowej (Hadfielda) Le Chatelier N.4 zalecane do napawania utwardzającego.

Napawanie elektrodami otulonymi było m.in. stosowane do remontów wozów bojowych w czasie II wojny światowej [14]. Były to prace prowadzone na ogromną skalę - obliczono, że np. na froncie wschodnim przy sprzyjających warunkach (gdy uszkodzone i niesprawne wozy nie pozostawały za liniami przeciwnika) przeciętny czołg był remontowany czterokrotnie, a tylko w ZSRR wyprodukowano ich w latach wojny ponad 100 tys. Napawanie z powodu swej czasochłonności nie było jednak w tym przypadku technologią dominującą - najczęściej stosowano spawanie, włącznie ze wstawianiem stalowych łat w celu naprawy konstrukcji staliwnych i żeliwnych.

Po wojnie napawanie wieloelektrodowe najczęściej stosowano w celu zwiększenia wydajności napawania łukiem krytym - liczba doprowadzanych równocześnie elektrod wynosiła czasem nawet 24 [15]. Informacje o wieloelektrodowym napawaniu pod topnikiem zaczęły pojawiać się w literaturze fachowej na samym początku lat 50. ub. stulecia [16]. W tym czasie, a i później napawanie traktowano głównie jako grupę technologii regeneracyjnych, a nie uszlachetniających powierzchnie nowych części i elementów. Na przykład w b. ZSRR należącym do czołówki państw, stosujących napawanie, jeszcze w połowie lat 70 . ub.w. ponad $70 \%$ zastosowań napawania dotyczyło prac regeneracyjno-remontowych [17]. 
Najwydajniejszą technologię napawania - napawanie elektrożużlowe - zaczęto stosować w Instytucie Spawania Elektrycznego E.O. Patona w Kijowie w 1951 r. Już pierwsze próby napawania elementów konstrukcji wielkich pieców obniżyły całkowity koszt ich remontu o $15 \%$. W przypadku konstrukcji grubościennych, gdzie napawanie można było stosować na większą skalę (np. młyny), efekty ekonomiczne były jeszcze bardziej znaczące [18].

W 1957 r. rozpoczęła się epoka technologii plazmowych - uruchomiono wtedy pierwszą maszynę do cięcia plazmowego, tzw. plazmotron. Pięć lat później ruszyła produkcja urządzeń do plazmowego spawania, a nieco później - napawania i natryskiwania. Pierwsze urządzenie generujące łuk plazmowy opracował inż. Schönner z firmy BASF jeszcze w 1908 r., ale jego praktyczne zastosowania były opanowywane powoli. Początkowo, w celu uzyskania napoin za pomocą strumienia gazu plazmowego topiono materiał dodatkowy w postaci drutu lub pręta, później zaczęto stosować materiał w postaci proszku, transportowany przez strumień gazu. Pierwsze firmy, specjalizujące się w napawaniu i natryskiwaniu plazmowym, zaczęły pojawiać się w USA pod koniec lat 60 . ub.w.
W Polsce pierwszą firmą, która rozpoczęła produkcję plazmotronów do nanoszenia warstw, był Instytut Badań Jądrowych w Świerku. Pierwsze urządzenia, np. PN-110 i PN-200 zaczęto tam opracowywać już w połowie lat 50 . ub.w., a prototyp plazmotronu do zautomatyzowanego napawania NP1-250 skonstruowano w Instytucie Spawalnictwa w Gliwicach w 1973 r. [19].

Najnowszą technologią napawania, stosowaną na szerszą skalę, jest napawanie laserowe. Po raz pierwszy zastosowano je pod kierunkiem D. Ghanamuthu w laboratorium firmy Rockwell International Corp. w Thousand Oaks w Kalifornii pod koniec lat 70. ub.w. [20]. Ponieważ prowadzono tam prace nad sprzętem wojskowym, podano jedynie, że napawanie laserowe zostało zastosowane do "nanoszenia nieporowatych powłok ceramicznych na podłoże metalowe". Początkowo stosowano podobno jedynie przetapianie warstw natryskiwanych termicznie (byłaby to więc jedna z pierwszych spawalniczych technologii hybrydowych), później materiał dodatkowy w postaci proszku lub drutu zaczęto doprowadzać bezpośrednio do strefy cieplnego oddziaływania wiązki laserowej.

\section{Podsumowanie}

Napawanie regeneracyjne, naprawcze i uszlachetniające jest obecnie uznaną i powszechnie stosowaną grupą technologii spawalniczych. W praktyce stosuje się niemal wszystkie $z$ opracowanych na przestrzeni stu lat technologii, systematycznie powstają też nowe metody napawania. Znaczący postęp jest notowany w dziedzinie materiałów dodatkowych do napawania. Na przestrzeni ostatnich dziesięcioleci największe zmiany nastąpiły w dziedzinie sterowania i kontroli procesu napawania, a zaawansowane metody badawcze i symulacyjne umożliwiły precyzyjne prognozowanie właściwości nanoszonych warstw. U podstaw tych ultranowoczesnych procesów leżą jednak niezmiennie pionierskie osiągnięcia minionych dziesięcioleci.

\section{Literatura}

[1] Pilarczyk J., Pilarczyk J.: Spawanie i napawanie elektryczne metali. Wyd. Śląsk, Katowice 1996.

[2] Kaiserliches Patentamt; Patentschrift Nr 38011, Verfahren der Metallbearbeitung mittels direkt angewendeten elektrischen Stromes. Klasse 48 - chemische Metallbearbeitung. Berlin, 31. Oktober 1885.

[3] Bernsdorf G.: Auf heissem Spuren vom Schmieden, Löten and Schweissen. VEB Fachbuchverlag, Leipzig 1986.

[4] Istoria Motovilikhinskich Zavodov, Perm 2008.

[5] Wassermann R.: Wie sparrt man Millionen durch Abbau der Ersatzteillager. Castolin Eutectic Institut, St. Sulpice/Lausanne 1971.

[6] Kaiserliches Patentamt; Patentschrift 231733. Klasse 21h, Gruppe 12, Elektrode und Verfahren zum elektrischen Löten. Berlin, 27. Juni 1908.

[7] Hasui A., Morigaki O.: Naplavka i napylenie. Masinostrojenie, Moskva 1985

[8] Materiały informacyjne firmy Thermadyne Industries Inc.

[9] Materiały informacyjne firmy Deloro Stellite.

[10] Prospekt firmy KSB Aktiengesellschaft.
[11] Szustakowski J.: Poradnik spawacza elektrycznego. WNT, Warszawa 1981

[12] Benardos N.N.: Naucno-tekhniceskije izobretienia i projekty. Naukova Dumka, Kiev 1982.

[13] Perun. Kalendarz Spawalniczy na rok 1935. Warszawa 1935.

[14] Friedli L.: Die Panzer Instandesetzung der Wehrmacht. Schneider Armour Research 2010.

[15] Dziubiński J., Klimpel A.: Napawanie i natryskiwanie cieplne. WNT, Warszawa 1985.

[16] Emelianov N.: Mnogoelektrodnaja elektrodugovaja i elektroslakovaja naplavka pod flusom. Transzeldorogizd, Moskva 1962

[17] Lejnacuk J.: Avtomaticna naplavka pid flusom pri remontnych rabotach. Derztechvidav. URSR, Kiiv 1959.

[18] Paton B.E.: Elektroslag Welding and Hardfacing. Mir, Moskva 1983.

[19] Szczeciński Z.: Kronika Instytutu Spawalnictwa z lat 19451996. Gliwice 1997.

[20] Ghanamuthu D.: Laser surface treatment. w: Optical Engineering SPIE. Vol.19, nr. 5/1980, Bellingham USA. 